\title{
Inter-Ethnic/Interracial Romantic Relationships in the United States: Factors Responsible for the Low Rates of Marriages Between Blacks and Whites
}

\author{
Amadu Jacky Kaba \\ Department of Sociology, Anthropology and Social Work, Seton Hall University, South Orange, USA. \\ Email: Amadu.Kaba@shu.edu \\ Received March 18 ${ }^{\text {th }}$, 2011; revised April 20 ${ }^{\text {th }}, 2011$; accepted May $23^{\text {rd }}, 2011$.
}

\begin{abstract}
This paper examines the status of interracial romantic relationships among non-Black groups and those between Blacks and non-Blacks in the United States. The research shows that, apart from Blacks, inter-ethnic/interracial marriages and other forms of romantic unions have increased substantially by the $21^{\text {st }}$ Century. For Black Americans, however, the data show that just a very tiny fraction of them are involved in interracial romantic relations, including marriages with Whites and other non-White groups. The paper then goes on to present the factors responsible for this phenomenon.
\end{abstract}

Keywords: Interracial Dating, Marriage, USA, African Americans, Wealth Transfer

\section{Introduction}

The literature on inter-ethnic/interracial romantic relations in the United States is beginning to increase at relatively large rates. Many of the studies on this topic suggest a visible and continuous increase in such unions by the $21^{\text {st }}$ Century. This is even the case with African Americans, who experienced the most severe restrictions to legally marry Whites. Politics has been the central factor in determining who marries interracially. In 1967, the Supreme Court of the United States finally ruled that antimisegenation laws were unconstitutional in the case Loving v. Virginia. Scholars and authors studying interracial marriages or unions are beginning to point to interesting research findings showing different trends in the kinds of unions being formed (Cready \& Saenz, 1997; Cretser \& Leon, 1982; Cruz \& Berson, 2001; Ellinghaus, 2002; Hwang, Saenz, \& Aguirre, 1995; Jacobs \& Labov, 1998, 2002; Kalmijn, 1993; Kennedy, 2003; McNamara, Tempenis, \& Walton 1999; Moran, 2001; Rogers, 1944; Tucker \& Mitchell-Kernan, 1990).

Attainment of higher levels of college/university or formal education has been cited by many scholars as an important factor in determining who marries interracially or inter- ethnically. Minorities in the United States with higher levels of education tend to marry interracially (Cready \& Saenz 1997; Kalmijn, 1993, 1998; Qian, 1997; Wong, 2003). As Blau et al. (1988) note, differences in individuals' life-chances increases as inequality rises. This leads to increase in differences in those individuals' customs and behaviors, taste and outlook in life: "As such social preferences are more different, the probability of marriage decreases” (p. 649).

This paper examines inter-ethnic/interracial romantic relationships in the United States, and the participation rates of African Americans in such unions. It shows that among non-Black groups, these relationships have become very common. The paper presents explanations for the factors that cause increase in inter-ethnic/interracial marriages in the United
States. The paper presents statistics showing that Black-White and Black-Other romantic relationship rates are very small relative to the tens of millions of Blacks in the United States. Finally, the paper goes on to present the factors responsible for the very tiny proportions of Blacks involved in interracial relationships including Black-White marriages.

\section{Overview of Inter-Ethnic/Interracial Romantic Relationships in the United States}

Human beings all across the world and throughout history have mixed inter-ethnically or interracially. This process of humans' “...urge to merge"1 has been cited as one primary reason for the various racial and ethnic groups that now inhabit the planet Earth.

Interracial marriages in the United States have increased substantially in the post-Civil Rights era. For example, there were 310, 000 interracial marriages in the United States in 1970 (.7\% of all marriages) (Qian, 1997: p. 263). As of March 2000, there were 1,047,000 interracial married couples and 165,000 interracial unmarried couples in the United States (Fields and Casper, 2001: p. 15). "This increase is interpreted as reflecting a positive change in race relations and a decline in racism” (Qian, 1997: p. 263). Crowder and Tolnay (2000) also claim that in 1960, interracial couples comprised less than 4 out of every 1,000 married couples in the United States. In 1998, that figure increased to over 24 per 1,000 married couples (p. 792).

Table 1 below shows statistics of married couples including interracial married couples in the United States in 1980 and 2007. According to Table 1 , in 1980 there were 49,714,000

${ }^{1}$ Quote from "Interview with Jonathan Marks.” Jonathan Marks is a molecular anthropologist who teaches at the University of North CarolinaCharlotte. He is author of Human Biodiversity and What It Means to Be 98\% Chimpanzee. Interview was for the television program entitled: "Race-The Power of an Illusion.” Aired in 2004 on PBS Television. Transcript at http://www.pbs.org/race/000_About/002_04-background-01-08.htm. 
married couples in the United States and by 2007 that number increased to $60,676,000$. Out of the 49,714,000 married couples in 1980,651,000 (1.3\%) comprised interracial married couples. Out of the 60,676,000 married couples in the U.S. in 2007, interracial married couples comprised 2,281,000 (3.76\%). In 1980, Black/White married couples comprised 167, 000 $(0.0033 \%)$ of all married couples. In 2007, Black/White married couples comprised 464,000 (0.008\%) of all married couples. In 1980, Black/Other race married couples comprised $34,000(0.0007 \%)$ of all married couples and 129,000 (0.002\%) in 2007. In 1980, White/Other race married couples accounted for $450,000(0.9 \%)$ of all married couples and 1,688,000 (2.8\%) of all married couples in 2007 (Table 1).

In the beginning of the $21^{\text {st }}$ Century, the U.S. has the most diverse people in the world, as a result of its gradual ethnic and racial merging. The ethnic and racial merging of the peoples (from the Old World, Africa, Asia and Europe; with the Western Hemisphere being the New World) in the U.S. is happening in four phases: 1) the successful intermarriage among the peoples who now constitute the White population 2) the gradual merging between this White population and non-Black minorities, for example, people from Asian countries such as Japan, China, India or Southeast Asian nations 3) inter-marriage between Black or African Americans and White Americans; and 4) inter-marriage between Blacks and non-Black minority groups.

Many of the ethnic groups now described as White in the U.S. were at one time classified as non-White. But as the level of tolerance in the country improved, the rate of inter-ethnic romantic relationships increased to the point where most Whites now have more than one ancestry. For example, in a report on the ancestries of Americans conducted for the U.S. Census, Brittingham and De la Cruz (2004) note that of the estimated 281.4 million people in the country in 2000, 62 million (22\%) listed multiple ancestries (p. 2; also see Kaba, 2006). That is a result of the high levels of inter-ethnic/interracial marriages or romantic relationships among Americans. Some of the early leaders of the country are said to have encouraged inter-

Table 1

Married couples in the United States by race and Hispanic origin of spouses: 1980 and 2007.

\begin{tabular}{|c|c|c|c|c|}
\hline & 1980 & & 2007 & \\
\hline Group & Number & $\begin{array}{l}\% \text { of } \\
\text { total }\end{array}$ & Number & $\begin{array}{l}\text { \% of } \\
\text { Total }\end{array}$ \\
\hline Total & $49,714,000$ & & $60,676,000$ & \\
\hline $\begin{array}{c}\text { Total Interracial } \\
\text { Married Couples }\end{array}$ & 651,000 & 1.3 & $2,281,000$ & 3.76 \\
\hline White/Black & 167,000 & 0.0033 & 464,000 & 0.008 \\
\hline Black husband/White wife & 122,000 & 0.0024 & 338,000 & 0.0056 \\
\hline White husband/Black wife & 45,000 & 0.0009 & 126,000 & 0.0021 \\
\hline White/Other race & 450,000 & 0.9 & $1,688,000$ & 2.8 \\
\hline Black/Other race & 34,000 & 0.0007 & 129,000 & 0.002 \\
\hline Hispanic/Hispanic & $1,906,000$ & 3.8 & $6,261,000$ & 10.3 \\
\hline $\begin{array}{l}\text { Hispanic/Other origin } \\
\text { (not Hispanic) }\end{array}$ & 891,000 & 1.8 & $2,241,000$ & 3.7 \\
\hline $\begin{array}{c}\text { All other couples } \\
\text { (not of Hispanic origin) }\end{array}$ & $46,917,000$ & 94.4 & $52,173,000$ & 86 \\
\hline
\end{tabular}

Source: Compiled and computed from "Table 59. Married Couples by Race and Hispanic Origin of Spouses: 1980 to 2007," Statistical Abstract of the United States. U.S. Census Bureau. Retrieved on September 5, 2009 from:

http://www.census.gov/compendia/statab/tables/09s0059.pdf ethnic and interracial romantic relationships. Brown (2001) notes that Thomas Jefferson, the nation's third president was quoted to have encouraged Indians and Whites to “...meet and blend together...intermix, and become one people” (p. 137).

Jeter (1982) points out that due to the rapid advancement of communication and transportation technologies, the rates of cross-ethnic/racial marriages have advanced to the point where they are "... closing space and providing time to test and experiment with one’s interpersonal relationships” (p. 105). In a review of the book The Melting Pot and the Altar: Marital Assimilation in Early Twentieth-Century Wisconsin (Bernard, 1981), Jeter (1982) points out that in 1880, the exogamy rates [the rate of marrying outside one's ethnic group or race] in Wisconsin for first and second-generation Eastern European immigrants were $21.0 \%$ and $30.8 \%$ respectively. In 1910 , the exogamy rates for Western European immigrants was 34.5\% for the first-generation and $46.6 \%$ for the second-generation. In Hawaii, Jeter notes that over half of all marriages by 1982 were intercultural (p. 105). As of March 2000, there were 452,000 White/Asian married couples in the United States comprising White males and Asian Pacific Islander (API) females, and 203, 000 married couples with API males and White females (Fields \& Casper, 2001)

Endogamy (marrying within one's ethnic group) is substantially lower in the U.S. for European ethnic groups than other racial groups. According to Kalmijn (1998), the estimated percentages of Americans who are married endogamously were 25\% for "(unmixed)" European ethnic subgroups, $75 \%$ for Asians subgroups, 65\% for Hispanic subgroups, $45 \%$ for American Indians and 95\% for African Americans (pp. 406-407). Religion has been influential in determining who members of particular religions or denominations must marry. Kalmijn (1998) points out that in the 1970s, an estimated 62\% of Catholics, $84 \%$ of Protestants and $80 \%$ of Jews were married endogamously (pp. 407-408). Sassler (2005: p. 626) presents a table (Table 3) entitled: "Exponentiated Coefficients for Outmarriage of White Ethnics, By Partner Choice” in the United States in 1910, and among the White ethnic groups listed are: English, Irish German, Italian, Jewish and Polish. According to Sassler (2005): "The English were evidently the most suitable marriage partners, acceptable both to other white ethnics and to the native stock. The Irish appear as second in the hierarchy of desirability for those selecting partners from outside their own ethnic group...Although outmarriage increased over the generations for Germans, it accelerated more rapidly among the Old ethnics” (pp. 626-627).

As the statistics above show, almost all of the ethnic/racial groups in the country have increased substantially the share of their members who marry or engaged in romantic relationships with members of other groups. One major exception has been African Americans, partly due to negative views of them by the larger society throughout the nation's history (Oliver \& Wong, 2003: p. 568). By the start of the $20^{\text {th }}$ Century, marriages between African Americans and Whites in "major American cities" were less than $1 \%$ of all African American marriages (Kalmijn, 1993: p. 122). Before examining the factors cited for the low rates of interracial romantic relationships between Blacks and Whites, and other groups, it is useful to present some factors for the relative increase in numbers of inter-ethnic/interracial marriages or unions in the United States. 


\section{Some Factors Cited for the Increase in Inter-Ethnic/ Interracial Marriages or Unions in the United States}

\section{Increase in Tolerance in the United States}

One important factor cited for the increased numbers of inter-ethnic/interracial romantic relationships or unions in the United States is the increase in tolerance among the people of the United States (Brace et al., 2002; Mondak \& Sanders, 2003). Mondak and Sanders (2003) point out that in measuring intolerance using a scale ranging from 0 - 15, with high scores representing intolerance, the level of intolerance declined from 7.24 in 1977 to 5.28 in 1998, a 27\% decline (pp. 493-494). According to Brace et al. (2002), from 1974-1998, 60\% of the people in the United States (excluding Hawaii, Idaho, Maine, Nebraska, Nevada and New Mexico) were tolerant (p. 176).

\section{Assimilation}

Assimilation, the gradual acceptance of minority groups into the larger mainstream society, has also been cited as a major contributor to the increase in inter-ethnic/interracial romantic relationships, including marriage in the United States (Acquye, 2007: p. 8; Gullickson, 2006: pp. 673-674; Jacobson \& Heaton, 2003: p. 1; Sassler, 2005: pp. 610-611). As Jacobson and Heaton (2003) note: "Inter-marriage between individuals of different racial and ethnic groups long has been used as an indicator of assimilation and acceptance of different racial and ethnic groups in society” (p. 1). According to Sassler (2005), "Intermarriage is often described as the final stage in the assimilation process" and points to an earlier study that notes that: “...assimilation paradigm posits that as immigrants acculturate to the norms and values of the host society, they will increasingly become acceptable marriage partners for members of the dominant group” (p. 610). Gullickson (2006) connected formal educational attainment to assimilation by noting that: “According to structural assimilation theory, education and educational system play key roles in the structural assimilation of groups because they promote universalistic and democratic norms, which tend to break down group barriers” (p. 675).

\section{Socioeconomic/Status Exchange Theory and Education}

Scholars have also pointed to the theory of Status Exchange, which is linked to Socioeconomic Status and education level of individuals in society as contributing factors to the visible increase in inter-ethnic/interracial romantic relationships, including marriage (Fenyo, 2001: p. 334; Fryer Jr., 2007: pp. 82 \& 85; Gullickson, 2006: pp. 674-675; Jacobson \& Heaton, 2003, 2008; Reiter et al., 2005: p. 451; Sassler, 2005: p. 611; Wang \& Kao, 2007: pp. 147 \& 155). "According to status-caste exchange theory...members of a lower-status group are more likely to marry members of a higher-status group if they can offer higher socioeconomic status to compensate for their lower racial status....The use of status-caste exchange theory to explain the nature of interracial pairing indicates an underlying hierarchical ordering of groups, with whites having the highest racial status, followed by Asians, Hispanics, and blacks...” (Wang and Kao, 2007: p. 147). Wang and Kao (2007) also point out that, “... we find that higher SES Hispanics are more likely to participate in interracial dating than their lower SES counterparts...” (p. 155). According to Jacobson and Heaton (2003): "Members of minority groups are said to exchange high socioeconomic advantage to overcome the socially perceived disadvantage of minority status...” (p. 3).

Gullickson (2006) points to two earlier studies that “....argued that interracial marriages would frequently involve an exchange of status characteristics. Highly educated blacks would trade their educational status in order to reap the benefits associated with the racial status of a potential white spouse. Similarly, whites with low levels of education would trade their racial status of a potential black spouse” (p. 674). Fryer Jr. (2007) notes that "Interracial marriages are now more concentrated among those with higher levels of education” (p. 79). Wang and Kao (2007) point to research that claims “...that those who engaged in interracial relationships have high education/economic status regardless of the race of their partners..." (p. 148). Jacobson and Heaton (2003) note that: "Education has been linked to higher rates of heterogamy... Like the military, colleges provide norms that are more accepting and tolerant of inter-racial dating than in the larger society. Colleges also provide increased opportunity for inter-group contact, dating, and marriage...” (p. 4).

\section{Geographic Location}

Geography plays an important role in the formation of inter-ethnic/interracial romantic relationships (Fryer Jr., 2007: pp. 81-82; Gullickson, 2006: pp. 676-677; Jacobson \& Heaton, 2008: p. 130; Kalmijn, 1998; Wang \& Kao, 2007). As Kalmijn (1998) notes, the chance or opportunity to meet a person from another ethnic/racial group depends “...on the way a group is dispersed geographically... Groups that are concentrated in specific regions of the country generally have more opportunity to marry endogamously than groups that are not” (p. 403). Wang and Kao (2007) point to research which claims that “...Hispanic and Asian Americans are more likely to live in predominantly white neighborhoods than are their African-American counterparts” (p. 148).

\section{Military}

The military is an institution that brings together males and females from all types of ethnic or racial backgrounds, thereby causing them to get to know one another, leading in some cases to inter-ethnic or interracial romantic relationships, including marriage. The military also moves its members from one region of the country to another and from one country or continent to another, thereby causing them to meet and interact with people from diverse backgrounds. According to Jacobson and Heaton (2003): "Because the military services promote an attitudinal environment that is often at variance with the traditional group and cultural norms, acceptance of other groups is higher in the military services than in society as a whole....In sum, military personnel have contact with other groups and cultures both in the United States and abroad, under favorable conditions, that may reduce resistance to outgroup marriage” (p. 2). Writing on the influence of the military on interracial romantic relationships, Fryer Jr. (2007) also points out that: "Soldiers are forced to interact and trust individuals of various ethnic and racial groups...The military is currently believed to be as racially integrated as any U.S. institution...” (pp. 80-81). 
Age

Age has also been cited for the increase in cross-cultural romantic relationships. Younger individuals are said to be more open to such relationships (Joyner \& Kao, 2000; McWhorter, 2003: pp. 70-71; Model \& Fisher, 2001; Reiter et al., 2005: pp. 449-450; Rosenfeld \& Kim, 2005; Wilensky, 2002). According to Model and Fisher (2001), “... younger people are expected to exhibit higher rates because the passage of time is associated with increasing tolerance for exogamy” (p. 179). Moreover, America's schools and colleges are more diverse than ever before and the teachers and professors are teaching students not to judge people based on their ethnic or racial backgrounds, rather they should judge people based on their character. Age seems to make a significant difference in the perception of interracial dating and marriages, with younger Americans showing less opposition to such relationships. In a public opinion poll, among those who answered that it is 'better to marry your own race, $68 \%$ were 65 years or over, $52 \%$ were 50 to 64 years, $34 \%$ were 30 to 49 years and $17 \%$ were 18 to 29 years (Fears, \& Deane, 2001). According to Reiter et al. (2005), in the United States: “...57\% of teenagers had dated someone outside their race, $30 \%$ had indicated that they would consider dating outside their race...” (p. 450).

Due to increased interactions between youths of all races and ethnicities, and the increase of television programs and Hollywood movies depicting interracial activities and relationships, most young people today of any race tend to be tolerant of members of other ethnic or racial groups. As McWhorter (2003) observes, “...increasingly movies for teens depict a world where, with no particular attention called to it, blacks and whites coexist in easy harmony” (pp. 70-71). Yancey (2002) notes that: "Perhaps the propagation of images of romantic interracial relationships through mass media has made interracial dating a viable practice regardless of which region one lives within” (p. 187).

Jeter (1982) presents examples provided by researchers for the motivations for inter-ethnic/interracial or cross-cultural marriages. Among the many examples presented are:

"Western marriage values love. Love may be the healthy tie that binds two people as well as the push to be involved in spite of cultural differences.

Chance and availability are important motives, especially for intercultural couples.

An adventuresome need to be different and an eagerness to be with the new is often a personality trait of partners in an intercultural marriage.

Reasons may be practical such as improvement of financial and social status.

A person may marry into the culture of an early caretaker.

Belief systems about other cultures may be the motive for a marriage” (p. 105).

Let us now turn to understanding why the factors cited above for the increase in interracial marriages in the United States only partially apply to Black Americans.

\section{Factors Responsible for Fewer Interracial Marriages Involving Black Americans}

If all of the reasons cited above have contributed to the relative high rates of cross-cultural and interracial romantic rela- tionships in the history of the United States, why have the rates of such relationships between Blacks and Whites, the two groups (apart from Native Americans) who are the oldest inhabitants of the country, been not as high as predicted or expected? Many scholars have attempted to answer this question (Breger \& Hill, 1998; Chatters, Taylor, \& Jayakody, 1994; Cruz \& Berson, 2001; Gordon-Reed, 1997; Hibbler \& Shinew, 2002; Hodes, 1999; Hughes, 2003; Johnson, 2004; Kalmijn, 1993; Kennedy, 2003; Leslie, 1996; McNamara, Tempenis, \& Walton, 1999; Moran, 2001; Rothman, 1998; Storrs, 1997; Wong, 2003).

The proportion of Whites and other non-Black minority groups in the United States that support interracial marriages between Blacks and non-Blacks has increased substantially. But the contradiction is that the rates of Black-White marriages are still extremely low, meaning that increase in support does not mean actually getting involve in marriages with Blacks. Moreover, even non-Black minorities also tend not to want to be in interracial marriages with Black Americans. A 1958 poll found that $96 \%$ of Whites disapproved of marriages between Blacks and Whites. However, in 1997, 77\% approved of such marriages (Kristof, 2004: p. A23). When the question "How do you think you would react if a member of your family told you they were going to marry [Black, White, Latino and Asian]...?” was asked, $86 \%$ of Black respondents answered that it would be fine with them if a member of their family married a white, $86 \%$ supported marrying an Asian, and 85\% supported marrying a Latino. For Latino respondents, $86 \%$ answered that they would be fine if a member of their family were to marry a White, $79 \%$ supported marrying an Asian, and 74\% supported marrying a Black person. For Asian respondents, 77\% answered that it would be fine with them if a member of their family were to marry a White, $71 \%$ supported marrying a Latino, and 66\% supported marrying a Black person. For Whites respondents, $66 \%$ answered that it would be fine with them if a member of their family were to marry a Latino, 65\% supported marrying an Asian, and 55\% supported marrying a Black person (Fears, \& Deane, 2001). The figures above show that significant proportions of Whites, Asians and Hispanics tend not to support family members who marry Blacks, partly due to negative views of Blacks (Oliver \& Wong, 2003: p. 569). Moreover, as already noted above, even with the majority of these non-Blacks showing support for marriages with Blacks, the actual marriage figures involving Black Americans are extremely low relative to the total Black and non-Black populations. For example, as of 2007, there were 40,744,000 Blacks or in combination with another race in the United States; 199,092,000 non-Hispanic Whites; 45,504,000 Hispanics; and13,080,000 Asians. $^{2}$ Let us now examine some interrelated factors responsible for this phenomenon.

\section{Family and Racial Community Acceptance of Inter- racial Romantic Relationships}

Authors and scholars have pointed out that African Americans are more accepting of interracial romantic relationships (Leslie, 1996). Leslie (1996) points to observations that White American families were less accepting of interracial romantic

${ }^{2}$ Source: "Table 6. Resident Population by Sex, Race, and Hispanic-Origin Status: 2000 to 2007,” Statistical Abstract of the United States. U.S. Census Bureau. Retrieved on September 19, 2009 from:

http://www.census.gov/compendia/statab/tables/09s0006.pdf. 
relationships than African American families. The reason for this was that Black mothers play a primary role within their families and that they tend to be more open and to relate to Whites than White men, who play a key role within their families, but tend to be less likely to accept people from outside racial groups. Leslie (1996) also claims that African American families tend to accept White in-laws because of an Africentric heritage, which normally "...emphasize the inclusion of blood grandchildren.... close blood ties among African American families are related more to this Africentric concept on immortality and strong family traditions than to clannishness” (pp. 530-531). Kalmijn (1993) notes that among the reasons why White women marry Black men is that "... white women are generally more tolerant towards blacks than white men are” (p. 140), and also points to a 1990 U.S. Census survey, however, that shows lower proportions of White men than White women who support laws banning Black-White marriages: “... 24\% of white women favored these laws, while only $17.4 \%$ of white men did so (N754). When we just focus on high school graduates, the difference is of a similar magnitude, $21.5 \%$ for women and $16.2 \%$ for men (p. 140).

Kalmijn (1993) notes that after the abolition of slavery, there began a gradual decline in the formal inequality that had previously existed between Blacks and Whites, especially in the southern United States. This decline in inequality caused concerns and anxiety among Whites because Blacks were beginning to cross boundaries that were once not available to them. As a result, Kalmijn points out that: "Interracial dating and marriage were condemned with great vigor, and social norms emerged against interracial contacts with possible erotic undertones, such as interracial dancing and swimming” and antimiscegenation laws were eventually passed (pp. 121-122).

According to Hibbler and Shinew (2002), a large portion of historical literature “... suggests that interracial marriage may have a number of negative effects on the couples and their children... Among the suggested negative effects are anxiety, insecurity, guilt, anger, depression, and identity conflicts” (p. 138). Discussing why a small percentage of Black men are married to White women, Wong (2003) claims that the mating taboo, individual differences and limited opportunities for courtship between Blacks and Whites are among the factors responsible (p. 804). Porterfield (1982) claims that due to the need “...to maintain their cohesiveness and identity" ethnic and racial groups develop rules to prevent intermarriages. Those rules may be based on variables such as social class, ethnic/racial, religious, cultural and political differences. Porterfield adds that: "No other mixture touches off such widespread condemnation as black-white race mixing" (p. 17).

The evidence also shows that both Blacks and Whites, for various reasons, have opposed interracial marriages (Kalmijn, 1993; Kennedy, 2003; Leslie, 1996; Mazrui, 2003; Paset \& Taylor, 1991; Storrs, 1997; Williams \& Thornton, 1998; Yancey, 2002), but such opposition does not necessarily mean racism, rather it is due to group pride (De Figueiredo Jr. \& Elkins, 2003; Herring, Jankowski, \& Brown, 1999). In a review of the book Multiracial Couples (Rosenblatt et al., 1995), Leslie (1996) summarizes the book by pointing out that:

"The authors note that the opposition of White families to interracial marriage had to do with matters of safety and wellbeing, the alleged clannishness of African American families, and the likelihood of a poor economic future. In contrast, African American families tended to oppose these marriages because of the risk of marrying down educationally, the importance of the sons of Black feminists marrying Black women, and the rejection of Black femininity that seems to be implied by Black sons marrying White women” (p. 530).

Storrs (1997) points out that, racial communities oppose interracial relationships because of the challenges they pose to both Black and White identity. For Blacks, Storrs notes that to marry out means disloyalty to the race, due largely to the African American community's emphasis on “...strong black identities.” In the case of Whites, Storrs notes that “... being involved in an interracial relationship made their whiteness salient in ways that most Euroamericans never experienced” (p. 326). Research shows that African Americans who are older, less-educated and reside in urban areas, and highly educated African Americans, who reside outside the Western region of the U.S., tend to feel closer bond with other African Americans (Williams \& Thornton, 1998: p. 256).

\section{Group Size and Third Party Influence}

Group size and Third Party Influence have been explained as contributing to the low rates of Black Americans involved in interracial romantic relationships, including marriages (Jacobson \& Heaton, 2003, 2008; Wang \& Kao, 2007). Jacobson and Heaton (2003) point to research that “....argue that relative group size is critical in determining the amount of outgroup contact that individuals are likely to experience. ... Since group size is inversely related to the chances that individuals will marry out of their own group, a setting where traditional barriers are low is likely to have higher than normal rates of intermarriage” (p. 2). Jacobson and Heaton (2003) also add that, "Cultural norms and prejudice are also part of the nexus of segregation” (p. 2). Wang and Kao (2007) write of group size by noting that "...the larger the relative group size, the smaller the chances that members from that group will participate in interracial dating” (p. 154).

Writing on the influence of "Third Parties" to negatively influence marriage between individuals, Jacobson and Heaton (2008) note that research “...has shown that third parties strongly influence rates of interracial marriage...even when segregation is not high, some individuals choose not to have contact with members of other groups, again reflecting the influence of third parties. The presence of large numbers of members of other groups may actually be perceived as a racial threat....Salient group identity and group sanctions are strong third-party influences” (p. 130). Johnson (2006) presents the following quote explaining how Whites reacted to the late great Black American boxing champion Jack Johnson's romantic relationships with White women:

Given that Black men were routinely terrorized and lynched on the strength of any hint that they had intimate associations with White women, the Black community was correct in assuming that Johnson's unapologetic romantic and sexual interest in women of that race would be taken as an audacious act of rebellion against the constraints of the American racial caste system. ...perhaps most immediately, there were also matters of ego-White men feared competition from Black men for the attention of women (p. 751). 


\section{Marginalization and Stigma}

Other factors that have been noted to influence interracial romantic relations involving Black Americans are Marginalization and Stigma (Alexander, 2007; Jacobson \& Heaton, 2008; Lehmiller \& Agnew, 2007; Twine \& Steinbugler, 2006; Vaquera \& Kao, 2005; Yancey, 2007). Twine and Steinbugler (2006) cite the research of Ruth Frankenberg (1993) in which Frankenberg:

“....argues that White women in primary relationships with people of color develop an acute awareness of the symbolic and material dimensions of racism. She suggests that, as intimates of Black men or women, White women experience 'rebound racism' through encounters that are secondhand and diffuse, but still painful. Racial pressures, she notes, also create tensions inside the relationship, as White partners struggle with their position vis-à-vis U.S. racism. Significantly, Frankenberg demonstrate that, through interracial intimacy, White women find themselves 'in changed positions in the racial order, albeit on contingent and provisional terms” (p. 343).

Yancey (2007) points to research that:

“...illustrates how racialization is connected to racial stigma....It is plausible to argue that interracial marriages containing African-Americans may suffer more in our racialized society than interracial marriages without African-Americans....research indicates that sanctions directed at marriages between whites and blacks are more powerful than sanctions directed at marriages between whites and non-black racial minorities. Because of the higher level of hostility, whites married to blacks may have different experiences than whites married to other racial minorities. These differential realities can reflect the potential racism black/white couples have historically faced and continue to experience" (p. 198).

Alexander (2007) writes that: "Although laws occasionally prevented other groups from intermarrying, all antimiscegenation laws criminalized marriage between blacks and whites. Moreover, the belief in the "one-drop rule," the idea that “"black blood' contaminated and overpowered 'white blood'," made black-white relationships more controversial than those between whites and members of other races” (pp. 218-219).

According to Lehmiller and Agnew (2007): “...individuals involved in primarily nontraditional romantic partnerships (i.e. same gender, interracial, and age gap...)” (p. 1036) perceive such unions as marginalized relationships and that it affects such unions:

"One possibility is that those who perceive higher levels of marginalization decide to keep their relationships secret from others. The consequences of secrecy, though, may include decrements in relationship satisfaction and overall relationship quality or increases in perceived relationship burden....Marginalization might lead to perceiving alternative romantic as more desirable to the extent that dissolving the current and selecting an alternative partner would reduce or eliminate felt prejudice (e.g., an interracial relationship partner selecting a partner from the same racial or ethnic group. Marginalization might also reduce the amount of social support that one receives for one's relationship” (Lehmiller \& Agnew, 2007, p. 1038).

According to Vaquera and Kao (2005): "There is some evidence from qualitative research suggesting that interracial couples do share common experiences with stigmatized individuals, such as social pressures and rejection, and that as a result they diminish their social exposure by going out less often to have dinner or to the movies...” (p. 486). In an interview with Television host Gil Noble, re-aired in the summer of 2009 on ABC television in New York City on a program called "Like It Is", the late prominent Black American entertainer and actor Sammy Davies Jr. acknowledged that when he married his White wife, he experienced a lot of pressure from both Black and White Americans who criticized him for marrying a White woman and that pressure eventually contributed to their divorce.

\section{The History of Forced Sexual Relations on Blacks by Whites in the United States}

The history of forced sexual relations upon Black Americans is a potential contributing factor as to why there are so few Black-White interracial marriages in the United States, despite the over 199 million non-Hispanic Whites and over 42 million Blacks in the country. This is because Black males and especially so Black females, want to have control of their bodies and determine who it is they want to enter into romantic relations with. Reading painful accounts of how Both White males and White females could force Blacks into sexual activities without their consent makes it difficult for most of the descendants of those Blacks to enter into romantic relationships with Whites-a psychological factor. According to Yarbrough (2005): "In the eyes of many ex-slaves, relationships between whites and blacks were usually matters of forced sex between the powerful and the powerless: '[I]mmoral white men have, by force, injected their blood into our veins...”” (p. 560). Yarbrough (2005) continues by writing that:

"The dynamics and differentials of power between masters and slaves complicate the notions of consent and choice. The subtext for interaction of this sort is the threat of violence: both slaves and masters recognized that masters could force their will upon slaves by means of physical punishment. The prospect of violent reprisal impinged on decisions by slaves to comply with or resist the sexual demands of masters....Ellen Sinclair recounted the incestuous tangle of relationships on the plantation where she grew up: 'Ol' man Anderson he hab a daughter by one of he slaves and he son hab a chile by dat daughter [his half-sister]. Dey mek de wimmen do what dey want and cose, dey slaves and coultn' help deyself” (p. 565).

Writing about the legacy of slavery in the U.S. pertaining to forced romantic relationships between Blacks and Whites, Firmin and Firebaugh (2008) note that: "Caucasian and African American Romantic relationships are not new and evidence suggests their occurrence from before the time of slavery. During slave times opposition between these two races was exacerbated by some slave owners raping African American women. Evidence also suggests that some Caucasian women used African American slaves as concubines” (p. 782).

In a study of 100 African American female college students, to determine their rates of interracial romantic relationships, Porter and Bronzaft (1995) found that $87 \%$ of them prefer Black males, $1 \%$ prefer White males, $4 \%$ prefer Hispanic males, $2 \%$ prefer Asian males and $2 \%$ prefer the group of males called “Other” (pp. 167-168).

\section{Politics/Laws Preventing Blacks from Interracial Marriages}

An important additional factor that is responsible for the very 
low proportion of Black-White marriages is that for a good portion of U.S. history, there actually existed laws banning interracial sex or marriages, especially those involving a person of Black African descent. Politics has been a primary factor for the unmet predictions of high rates of marriages between Blacks and Whites in the United States.

For example, Fryer Jr. (2007) presents a table (Table 1) showing states that never had laws prohibiting interracial marriage: Alaska, Connecticut, Hawaii, Kansas (such a law existed, but repealed before statehood), Minnesota, New Hampshire, New Mexico (such a law existed, but repealed before statehood), New Jersey, New York (a law existed against interracial sex when it was New Amsterdam, a colony of the Dutch), Vermont, Washington (such a law existed, but repealed before statehood), and Wisconsin.

The following states repealed laws prohibiting interracial marriages before 1900: Illinois (1874), Iowa (1851), Maine (1883), Massachusetts (1843), Michigan (1883), Ohio (1887), Pennsylvania (1780), and Rhode Island (1881). The following states repealed laws prohibiting interracial marriages after 1900 and before the 1967 Loving decision: Arizona (1962), California (1948), Colorado (1957), Idaho (1959), Indiana (1965), Maryland (1967), Montana (1953), Nebraska (1963), Nevada (1959), North Dakota (1955), Oregon (1951), South Dakota (1957), Utah (1963), and Wyoming (1965).

Finally, the following states repealed laws prohibiting interracial marriage after the 1967 U.S. Supreme Court Loving decision, claiming that such laws were unconstitutional: Alabama, Arkansas, Delaware, Florida, Georgia, Kentucky, Louisiana, Mississippi, Missouri, North Carolina, Oklahoma, South Carolina, Texas, Tennessee, Virginia, and West Virginia (p. 74).

\section{Concern about the Potential Transfer of Wealth in Interracial Marriages}

Another important factor that might have caused opposition to interracial marriages, especially Black-White marriage is economics, money or the concern for the potential transfer of wealth. Cruz and Berson (2001) note that "economic exploitation” was the real reason for miscegenation laws (p. 80). Oliver and Wong (2003) also present a similar observation (p. 569). Let me attempt to explain how the concern for transfer of wealth in interracial marriages leads to the small number of Black-White marriages. For Whites, since White men in particular have an advantage than everyone else in society to earn higher incomes and the inheritance laws of the U.S. give the surviving spouse the rights to all of the wealth acquired during marriage, they find it useful to oppose such marriages because of fear of a White husband dying and a Black female spouse taking over their estate. The same also happens when a Black man marries a White woman and since he is likely to die before his White wife, and as the data above show that highly accomplished Black males marry White females, then these Black males are more likely to transfer their wealth to the White Wife and thereby the White race.

This transfer of wealth actually impacts the Black community more severely, because proportionally, there are fewer wealthy Blacks than Whites and the life expectancy of Blacks is lower than that for Whites. For example, in 2006, out of 94,029,000 White alone males, $6,018,000$ (6.4\%) earned $\$ 100,000$ or more; 299,000 (2.35\%) out of 12,716,000 Black alone males; 2,606,000
(2.7\%) out of 97,550,000 White alone females; and 213,000 (1.4\%) out of 15, 413, 000 Black alone females. ${ }^{3}$ As of 2005, the average life expectancy at birth in the United States was 77.8 years; 80.8 years for White females; 76.5 years for Black females; 75.7 years for White males and 69.5 years for Black males. ${ }^{4}$

\section{Conclusion}

The data in this paper have illustrated that by the beginning of the $21^{\text {st }}$ Century, inter-ethnic marriages or romantic unions have increased substantially among those individuals categorized as White in the United States. There has also been a significant increase in the number of marriages or romantic unions between individuals in this White group and non-Black minority groups in the United States. For Black Americans, the data reveal that while there is a visible increase of them getting involved in interracial marriages or romantic unions, overall, it is a very tiny fraction for a group with over 42 million members. It appears that the very low rates of interracial marriages between Blacks and Whites have influenced or impacted similar relationships between Blacks and other non-Black minority groups in the United States.

\section{References}

Acquye, R. (2007). Interracial marriage. Network Journal, 14, 8.

Alexander, E. (2007). For better or for worse: Marriage across boundaries. Journal of Women's History, 19, 213-221.

doi:10.1353/jowh.2007.0049

Bernard, R. M. (1981). The melting pot and the altar: Marital assimilation in early twentieth-century Wisconsin. Minneapolis, MN: University of Minnesota Press.

Blau, P. M., Blum, T., Rytina, S., \& Schwartz, J. (1988). Inequality and intermarriage: A parado of motive and constraint. Social Forces, 66, 645-675. doi:10.2307/2579570

Brace, P., Butler, K. S., Arceneaux, K., \& Johnson, M. (2002). Public opinion in the American states: New perspectives using national survey data. American Journal of Political Science, 46, 173-189. doi: $10.2307 / 3088421$

Breger, R., \& Hill, R. (1998). Cross-cultural marriage: Identity and choice. Oxford: Berg.

Brittingham, A., \& De la Cruz, G. P. (2004). Ancestry: 2000. U.S. Census Bureau. Washington, D.C.: Government Printing Office.

Brown, H. (2001). The horrid alternative: Miscegenation and madness in the frontier romance. Journal of American \& Comparative Cultures, 24, 137-151. doi:10.1111/j.1537-4726.2001.2403_137.x

Chatters, L. M., Taylor, R. J., \& Jayakody, R. (1994). Fictive kinship relations in black extended families. Journal of Comparative Family Studies, 25, 297.

Cready, C. M., \& Saenz, R. (1997). The nonmetro/metro context of racial/ethnic outmarriage: Some differences between African Americans and Mexican Americans. Rural Sociology, 62, 335-362. doi:10.1111/j.1549-0831.1997.tb00655.x

Cretser, G. A., \& Leon, J. J. (1982). Intermarriage in the U.S.: An overview of theory and research. Marriage \& Family Review, 5, 3. doi:10.1300/J002v05n01_02

Crowder, K. D, \& Tolnay, S. E. (2000). A new marriage squeeze for

${ }^{3}$ Source: "Table 683. Money Income of People-Number by Income Leve and by Sex, Race, and Hispanic Origin: 2006,” 2009 Statistical Abstract of the United States. U.S. Census Bureau. Retrieved on May, 3, 2009 from: http://www.census.gov/compendia/statab/tables/09s0683.pdf.

${ }^{4}$ Source: "Table 103. Expectation of Life and Expected Deaths by Race, Sex and Age: 2005,” 2009 Statistical Abstract of the United States. U.S. Census Bureau. Retrieved on September 23, 2009 from:

http://www.census.gov/compendia/statab/tables/09s0103.pdf. 
black women: The role of racial intermarriage by black men. Journal of Marriage and the Family, 62, 792-807.

doi:10.1111/j.1741-3737.2000.00792.x

Cruz, B. C. \& Berson, M. J. (2001). The American melting pot? Miscegenation laws in the United States. Magazine of History, 15, 80-84. doi:10.1093/maghis/15.4.80

De Figueiredo, R. J. P. Jr., \& Elkins, Z. (2003). Are patroits bigots? An inquiry into the vices of in-group pride. American Journal of Political Science, 47, 171-188. doi:10.1111/1540-5907.00012

Ellinghaus, K. (2002). Margins of acceptability. Frontiers, 23, 55-75. doi:10.1353/fro.2003.0005

Fears, D., \& Deane, C. (2011) Race, dating and marriage. In Biracial couples report tolerance (p. A01). Washington Post.

http://www.washingtonpost.com/wp-srv/nation/sidebars/polls/biracia 1070501.htm.

Fenyo, M. D. (2001). Cross-cultural marriage: Identity and choice. Journal of Third World Studies, 18, 334-335.

Fields, J., \& Casper, L. M. (2001). America's families and living arrangements 2000. U.S. Census Bureau, Table FG3. P20-537. Washington, DC: Government Printing Office.

Firmin, M. W., \& Firebaugh, S. (2008). Historical analysis of college campus interracial dating. College Student Journal, 42, 782-788.

Frankenberg, R. (1993). White women, race matters: The social construction of whiteness. Minneapolis, MN: University of Minnesota Press.

Fryer, R. G. Jr. (2007). Guess who's been coming to dinner? Trends in interracial marriage over the $20^{\text {th }}$ century. Journal of Economic Perspectives, 21, 71-90. doi:10.1257/jep.21.2.71

Gordon-Reed, A. (1997). Thomas Jefferson and Sally Hemings: An American controversy. Charlottesville and London: University Press of Virginia.

Gullickson, A. (2006). Education and black-white interracial marriage. Demography, 43, 673-689. doi:10.1353/dem.2006.0033

Herring, M., Jankowski, T. B., \& Brown, R. E. (1999). Pro-black doesn't mean anti-white: The structure of African American group identity. Journal of Politics, 61, 363-386. doi:10.2307/2647508

Hibbler, D. K., \& Shinew, K. J. (2002). Interracial couples' experience of leisure: A social work approach. Journal of Leisure Research, 34, 135-156.

Hodes, M. (1999). Sex, love, race: Crossing boundaries in North American history. New York: New York University Press.

Hughes, Z. (2003). Why some sisters only date whites \& "others." Ebony, 58, 55-58.

Hwang, S., Saenz, R., \& Aguirre, B. E. (1995). The SES selectivity of interracially married Asians. International Migration Review, 29, 469-491. doi: $10.2307 / 2546790$

Jacobs, J. A., \& Labov, T. (1998). Preserving multiple ancestry: Intermarriage and mixed births in Hawaii. Journal of Comparative Family Studies, 29, 481-502.

Jacobs, J. A., \& Labov, T. (2002). Gender differentials in intermarriage among sixteen race and ethnic groups. Sociological Forum, 17, 621-646. doi:10.1023/A:1021029507937

Jacobson, C. K., \& Heaton, T. B. (2008). Comparative patterns of interracial marriage: Structural opportunities, third-party factors, and temporal change in immigrant societies. Journal of Comparative Family Studies, 39, 129-149.

Jacobson, C. K., \& Heaton, T. B. (2003). Inter-group marriage and United States military service. Journal of Political and Military, Sociology, 31, 1-22.

Jeter, K. (1982). Intercultural and interracial marriage. Marriage \& Family Review, 5, 105. doi:10.1300/J002v05n01_10

Johnson, K. R. (2006). The legacy of Jim Crow: The enduring taboo of black-white romance. Texas Law Review, 84, 739-766.

Johnson, T. A. (2004). Colonial caste paradigms and the African diaspora. The Black Scholar, 34, 23-33.

Joyner, K., \& Kao, G. (2000). School racial composition and adolescent racial Homophily. Social Science Quarterly, 81, 810.

Kaba, A. J. (2006). The blood and family relations between Africans and Europeans in the United States. African Renaissance, 3, 105-114.
Kalmijn, M. (1993). Trends in black/white intermarriage. Social Forces, 72, 119-146. doi:10.2307/2580162

Kalmijn, M. (1998). Intermarriage and homogamy: Causes, patterns, trends,” Annual Review of Sociology, 24, 395-421.

doi:10.1146/annurev.soc.24.1.395

Kennedy, R. (2003). Interracial intimacies: Sex, marriage, identity, and adoption. New York: Pantheon Books.

Kristof, N. D. (2004). Marriage: Mix and match. New York Times, p. A-23.

Lehmiller, J. J., \& Agnew, C. R. (2007). Perceived marginalization and the prediction of romantic relationship stability. Journal of Marriage and Family, 69, 1036-1049. doi:10.1111/j.1741-3737.2007.00429.x

Leslie, A. R. (1996). Multiracial couples. Journal of Marriage and the Family, 58, 530-531. doi:10.2307/353519

Mazrui, K. F. (2003). Live and let love: Self-determination in matters of intimacy and Identity. Michigan Law Review, 101, 2185-2208. doi:10.2307/3595351

McNamara, R. P., Tempenis, M., \& Walton, B. (1999). Crossing the line: Interracial couples in the South. Westport, CT: Praeger.

McWhorter, J. (2003). Authentically black. Essays for the black silent majority. New York: Gotham Books.

Model, S., \& Fisher, G. (2001). Black-white unions: West Indians and African Americans compared,” Demography, 38, 177-185. doi:10.1353/dem.2001.0019

Mondak, J., \& Sanders, M. S. (2003). Tolerance and intolerance, 1976-1998. American Journal of Political Science, 47, 492-502. doi:10.1111/1540-5907.00035

Moran, R. F. (2001). Interracial intimacy: The regulation of race \& romance. Chicago, Illinois: University of Chicago Press.

Oliver, J. E., \& Wong, J. (2003). Inter-group prejudice in multiethnic settings. American Journal of Political Science, 47, 567-582. doi: $10.2307 / 3186119$

Paset, P. S., \& Taylor, R. D. (1991). Black and white women's attitudes toward interracial marriage. Psychological Reports, 69, 753. doi: $10.2307 / 2967239$

Porter, M. M., \& Bronzaft, A. L. (1995). Do the future plans of educated black women include black mates. The Journal of Negro Education, 64, 162-170. doi:10.2466/PR0.69.7.753-754

Porterfield, E. (1982). Black-American intermarriage in the United States. Marriage \& Family Review, 5, 17. doi:10.1300/J002v05n01_03

Qian, Z. (1997). Breaking the racial barriers: Variations in interracial marriage between 1980 and 1990. Demography, 34, 263-276. doi:10.2307/2061704

Reiter, M. D., Krause, J. M., \& Stirlen, A. (2005). Intercouple dating on college campus. College Student Journal, 39, 449-454.

Rogers, J. A. (1944). Sex and race Vol. III . Renewed in 1972 by Helga M. Rogers. $497559^{\text {th }}$ Avenue South St. Petersburg, Fl 33715. ISBN 09602294-2-6.

Rosenblatt, P. C., Karis, T., \& Powell, R. R. (1995). Multiracial couples: black \& white voices. Thousand Oaks, CA:Sage Publications.

Rosenfeld, M., \& Kim, B. S. (2005). The independence of young adults and the rise of interracial and same-sex unions. American Sociological Review, 70, 541-562.

doi:10.1177/000312240507000401

Rothman, J. D. (1998). To be freed from thate curs and let at liberty: Interracial adultery and divorce in Antebellum Virginia. The Virginia Magazine of History and Biography, 106, 443-481.

Sassler, S. (2005). Gender and ethnic differences in marital assimilation in the early twentieth century. The International Migration Review, 39, 608-636. doi:10.1111/j.1747-7379.2005.tb00282.x

Storrs, D. (1997). Multiracial couples: Black and white voices. Journal of Comparative Family Studies, 28, 325-327.

Tucker, M. B., \& Mitchell-Kernan, C. (1990). New trends in black American interracial marriage: The social structural context. Journal of Marriage and the Family, 52, 209-218. doi:10.2307/352851

Twine, F. W., \& Steinbugler, A. C. (2006). The gap between whites and whiteness: Interracial intimacy and racial literacy. Du Bois Review, 3, 341-363. doi:10.1017/S1742058X06060231 
Vaquera, E., \& Kao, G. (2005). Private and public displays of affection among interracial and intra-racial adolescent couples. Social Science Quarterly, 86, 484-508. doi:10.1111/j.0038-4941.2005.00314.x

Wang, H., \& Kao, G. (2007). Does higher socioeconomic status increase contact between minorities and whites? An examination of interracial romantic relationships among adolescents. Social Science Quarterly, 88, 146-164. doi:10.1111/j.1540-6237.2007.00451.x

Wilensky, J. (2002). Relationships. Human Ecology, 30, 16-18.

Williams, T. K., \& Thornton, M. C. (1998). Social construction of ethnicity versus personal experience: The case of Afro-Amerasians. Journal of Comparative Family Studies, 29, 255-267.

Wong, L. Y. (2003). Why do only $5.5 \%$ of black men marry white women. International Economic Review, 44, 803-826. doi:10.1111/1468-2354.t01-1-00090

Yarbrough, F. A. (2005). Power perception, and interracial sex: Former slaves recall a multiracial South. The Journal of Southern History, 71, 559-588. doi:10.2307/27648820

Yancey, G. (2007). Experiencing racism: Differences in the experiences of whites married to blacks and non-black racial minorities. Journal of Comparative Family Studies, 38, 197-213.

Yancey, G. (2002). Who interracially dates: An examination of the characteristics of those who have interracially dated. Journal of Comparative Family Studies, 33, 179-190. 